\title{
PRÓBA KLASYFIKACJI GMIN \\ WOJEWÓDZTWA WARMIŃSKO-MAZURSKIEGO Z PUNKTU WIDZENIA ICH SYTUACJI FINANSOWEJ
}

\section{WSTĘP}

Jednostki terytorialne w Polsce różnią się między sobą pod względem społeczno-gospodarczym, kulturowym, uwarunkowań naturalnych, warunków historycznych itp. Rezultatem oddziaływania wszystkich tych czynników jest utrzymywanie się wieloaspektowych różnic w regionach, subregionach, a także sasiadujacych ze sobą układach lokalnych na poziomie gmin. Przejawem oddziaływania wymienionych czynników jest również zróżnicowanie budżetów gmin - ich poziomów, źródeł pozyskiwania dochodów i kierunków wydatkowania środków. W zwiąku z tym trudno jest formułować ogólne, obiektywne i adekwatne zalecenia dla polityki budżetowej poszczególnych gmin np. w okresach pogorszenia sytuacji makroekonomicznej kraju lub przy wprowadzaniu nowych instytucji prawnofinansowych dotyczących jednostek samorządu terytorialnego (JST) w Polsce. Trudno jest także zidentyfikować szczegółowe czynniki, które kształtują budżety gmin. Z pewnością przezwyciężenie tych trudności mogłoby przyczynić się do przyspieszenia rozwoju gospodarczego gmin i regionów, zwłaszcza tych o szczególnie trudnej sytuacji gospodarczej.

W związku z powyższym oraz mając na uwadze wielość gmin, w niniejszym opracowaniu podjęto próbę pogrupowania gmin z punktu widzenia oceny ich sytuacji finansowej. W celu ograniczenia wpływu na wyniki badań obiektywnych różnic w warunkach funkcjonowania regionów Polski badaniami zostały objęte gminy jednego województwa - warmińsko-mazurskiego. Województwo to leży w północno-wschodniej części Polski i jest czwartym co do wielkości jej regionem. Jest jednym z najsłabiej rozwiniętych pod względem gospodarczym obszarów Polski, czego przejawami są m.in. niski wskaźnik PKB przypadający na jednego mieszkańca, wysokie bezrobocie, niski wskaźnik urbanizacji. Region ten spełnia cechy obszaru peryferyjnego.

Zakres czasowy badań obją lata 2010-2014, a więc okres pierwszych pięciu lat po kryzysie gospodarczym, który rozpoczą się w latach 2008-2009, którego skutki w zakresie finansów JST dostrzegalne są do dzisiaj. Kryzys ten przyniósł większości gmin pogorszenie sytuacji finansowej, w szczególności dotkną budżety dużych miast. Zmniejszanie się dochodów własnych i wzrost liczby zadań jednostek samorządowych skutkowały nadmiernym poziomem zobowiązań. Temu natomiast przeciwdziałać miały ustanowione prawnie gra- 
nice zadłużenia JST ${ }^{1}$, które ograniczają ich możliwości inwestycyjne, a przez to stanowia barierę rozwojową. Opisywane zmiany są szczególnie widoczne w początkach drugiej dekady XXI w. ${ }^{2}$

W artykule wykorzystano dane statystyczne pochodzące z Banku Danych Lokalnych GUS oraz Ministerstwa Finansów. Wszystkie obliczania statystyczne wykonano za pomoca programu STATISTICA v. 12 . W pracy przedstawiono podstawy teoretyczne oraz zastosowanie praktyczne grupowania metodą $k$-średnich. Wykorzystano także analizę wskaźnikową budżetów gmin, dzięki której wyodrębniono zmienne przesądzajace o zaklasyfikowaniu gmin do danej grupy. Analiza wielowymiarowa, w tym grupowanie metoda $k$-średnich JST z punktu widzenia oceny ich budżetów lub innych czynników, nie jest nowym zagadnieniem badawczym. Badania takie na gruncie polskim prowadzili np. Marcin Wiśniewski ${ }^{3}$, Przemysław Śleszyński ${ }^{4}$ i Marcin Hyski ${ }^{5}$. Jednakże wykorzystanie metod wielowymiarowych może przynosić za każdym razem nowe efekty i inne ujęcia rozważanych zagadnień, a także dawać asumpt do dalszych poszukiwań i praktycznych rozwiąań np. w zakresie racjonalizacji finansów JST.

W efekcie dokonanej klasyfikacji wyodrębniono pięć grup gmin. Dokonano ich charakterystyki i wskazano na podobieństwa cech ich budżetów, a także wykazano różnicujące cechy gmin sklasyfikowanych w oddzielnych grupach. Zastosowany podział gmin umożliwił również tzw. profilowanie grup przez odniesienie wyników klasyfikacji do statusu prawnego gmin województwa oraz do ich położenia administracyjnego. Dodatkowo utworzono ranking poszczególnych grup gmin. Dokonana klasyfikacja posłuży w przyszłości do ustalenia szczegółowych czynników determinujących budżety gmin województwa oraz sformułowania rekomendacji dla polityki budżetowej sklasyfikowanych jednostek.

\section{KLASYFIKACJA JAKO METODA BADAWCZA}

Klasyfikacja jest zespołem czynności, które polegają na wyodrębnieniu z $n$ -elementowego zbioru $X$, niepustych $k$-podzbiorów $X_{1}, X_{2}, \ldots, X_{\mathrm{k}}$ (gdzie $i=1$, $2, \ldots, k)$, pod warunkiem, że suma $k$-podzbiorów $X_{1} \cup X_{2} \cup \ldots \cup X_{\mathrm{k}}$ jest równa $X$ (warunek adekwatności) oraz iloczyn podzbiorów $X_{\mathrm{i}} \cap X_{\mathrm{j}}(i \neq j=1,2, \ldots, k)$ jest zbiorem pustym $\varnothing$ (warunek rozłączności). Oznacza to, że suma podzbiorów jest tożsama ze zbiorem głównym, natomiast poszczególne podzbiory nie zawierają elementów wspólnych.

Wyodrębnione podzbiory określa się mianem członków klasyfikacji, grup lub klas. Zaliczenie do określonej klasy obiektów związane jest z posiadaniem

\footnotetext{
1 M. Poniatowicz, Wpływ kryzysu gospodarczego na systemy finansowe jednostek samorzqdu terytorialnego na przykładzie największych miast $w$ Polsce, CeDeWu.PL, Warszawa 2014, s. 8-9.

2 K. Surówka, Samorząd terytorialny $w$ Polsce $w$ dobie spowolnienia gospodarczego. „Nierówności Społeczne a Wzrost Gospodarczy” 2014, nr 1(37), s. 376.

${ }^{3}$ M. Wiśniewski, Sytuacja finansowa gmin i miast na prawach powiatu $w$ Polsce $w$ okresie kryzysu, „Zeszyty Naukowe Uniwersytetu Ekonomicznego w Poznaniu” nr 2011(202), s. 77-93.

${ }^{4}$ P. Śleszyński, Klasyfikacja gmin województwa mazowieckiego, „Przegląd Geograficzny” 84, 2012, z. 4, s. 559-576.

${ }_{5}^{5}$ M. Hyski, Typologia obszarów wiejskich województwa śląkiego pod względem wyposażenia infrastrukturalnego, „Infrastruktura i Ekologia Terenów Wiejskich” 2008, nr 2, s. 115-127.
} 
przez te obiekty własności, która może mieć jedno- lub wielocechowy charakter będący kryterium klasyfikacji. Poszczególne elementy klas są do siebie podobne i można je traktować jako prawie identyczne z punktu widzenia branej pod uwagę własności. Elementy w danej klasie charakteryzują się relacja równoważności ${ }^{6}$.

Klasyfikacja spełnia rolę uogólniającą w opisie przedmiotu badań oraz funkcję poznawczą badanych obiektów w przekroju wyszczególnionych elementów lub w przekroju wydzielonych klas. Dzięki klasyfikacji następuje redukcja wielu rozproszonych informacji o uwarunkowaniach badanego zjawiska. Może być ona etapem pośrednim w poszukiwaniu lub zweryfikowaniu posiadanych informacji, dzięki czemu może nadać dalszy kierunek badań.

Wśród metod klasyfikacji można wyróżnić klasyfikacje jednocechowe oraz wielocechowe. W przypadku budżetów gmin i rozpatrywanych mierników sytuacji finansowej adekwatnym sposobem grupowania jest metoda analizy skupień odnosząca się do grupowania obiektów pod kątem wielu wyodrębnionych cech. Analiza skupień służy do wykrywania istniejacych struktur w przedmiocie badań bez podawania i wyjaśniania ich przyczyn.

Istnieje wiele metod grupowania w ramach analizy skupień oraz ich podziałów. Wśród nich można wyróżnić m.in. metody hierarchiczne, które przede wszystkim umożliwiają określenie liczby skupień w badanej zbiorowości. Efektem takiego podziału jest drzewo hierarchiczne (dendagram), które jest użytecznym narzędziem do określenia liczby skupień w badanej zbiorowości. W tym celu w niniejszym artykule posłużono się najpopularniejszą metoda aglomeracji - metodą Warda, która wykorzystuje analizę wariancji i polega na minimalizacji odchyleń wewnątrz skupień ${ }^{7}$.

Kolejnym krokiem po określeniu liczby skupień jest grupowanie poszczególnych obiektów do danej klasy według wybranej metody grupowania o charakterze niehierarchicznym. Jednym ze sposobów grupowania obiektów w analizie skupień jest metoda $k$-średnich. Jej efektem jest rozbicie zbiorowości na klika wskazanych uprzednio grup (skupień), w których żaden element jednego skupienia nie należy do elementów innego skupienia. Polega ona więc na wyodrębnieniu $k$-skupień tak, aby obiekty w nich zgrupowane były najbardziej do siebie zbliżone oraz aby obiekty w odrębnych skupieniach różniły się od siebie możliwie w jak największym stopniu.

Istnieje wiele wariantów metody $k$-średnich, które wyodrębniane sa z punktu widzenia kryterium grupowania poszczególnych elementów, metody ustalania środków ciężkości pierwotnej konfiguracji klas, a także przemieszczania poszczególnych jednostek podczas optymalizacji grupowania lub sposobu zakończenia grupowania ${ }^{8}$. Bez względu na wykorzystaną wersję metody $k$-średnich, jej algorytm jest podobny i przebiega według punktów ${ }^{9}$ :

${ }^{6}$ M. Walesiak, Problemy decyzyjne w procesie klasyfikacji zbioru obiektów, „Prace Naukowe Akademii Ekonomicznej we Wrocławiu” 2004, nr 1010, s. 52-60.

7 A. Stanisz, Przystepny kurs statystyki z zastosowaniem STATISTICA PL na przykładach $z$ medycyny, t. 3: Analizy wielowymiarowe, StatSoft Polska, Kraków 2007, s. 122.

8 T. Grabiński, S. Wydymus, A. Zeliaś, Metody taksonomii numerycznej $w$ modelowaniu zjawisk społeczno-gospodarczych, PWN, Warszawa 1989, s. 78.

9 A. Kajstura, Metoda k-średnich, http://www.statystyka.az.pl/analiza-skupien/metoda-k-srednich. php [dostęp: 30.12.2016]. 
1) ustalenie liczby skupień w oparciu o wybór arbitralny lub przez zastosowanie analiz formalno-merytorycznych;

2) wstępne ustalenie środków skupień, np. na podstawie losowego wyboru $k$-obserwacji bądź wyboru $k$-pierwszych obserwacji, bądź w sposób, który zmaksymalizuje odległości skupień lub losowy wybór skupień;

3) wyznaczenie odległości od środka skupień, np. przy zastosowaniu odległości euklidesowej lub kwadratu tej odległości;

4) odpowiednie przypisanie jednostek do skupień na skutek porównania odległości od wszystkich skupień i ustalenia środka, do którego ma najbliżej;

5) ustalenie nowych środków skupień, które najczęściej są średnią współrzędnych punktów należących do skupienia;

6) wykonanie poprzednich kroków do momentu spełnienia warunku zatrzymania, którym jest najczęściej wykonanie ilości iteracji ustalonej na początku badania lub brak przesunięć jednostek pomiędzy skupieniami. Zazwyczaj wystarczy do 10 iteracji, aby uzyskać ostateczne grupowanie obiektów ${ }^{10}$.

W niniejszym artykule zastosowano sortowanie obiektów według odległości, a na centra skupień zostały wybrane obiekty przy stałych interwałach ${ }^{11}$.

\section{DOBRÓR WSKAŹNIKÓW (CECH) OPISUJĄCYCH SYTUACJĘ FINANSOWĄ GMIN}

Podstawową metodą umożliwiającą kontrolę finansów JST oraz ich planowanie jest szeroko rozumiana analiza finansowa. Służy ona do badania struktury, cech i zależności dotyczących określonego zjawiska finansowego danej jednostki. Analiza dochodów i wydatków budżetowych w gminach przyczynia się do poznania i oceny przebiegu procesów i zjawisk w niej zachodzacych. Jest ona także podstawą do stawiania diagnoz o stanie finansów i punktem wyjścia określania alternatyw decyzyjnych w przyszłości ${ }^{12}$.

Przekrojami analizy budżetów są: analiza pionowa dotycząca struktury budżetów, analiza pozioma umożliwiajacca porównywanie w czasie poszczególnych pozycji budżetu oraz analiza wskaźnikowa wykorzystująca relatywne miary budżetowe służące do ich oceny. Dzięki tej ostatniej możliwa jest zwłaszcza analiza porównawcza „podobnych” jednostek samorządu.

Obszerna literatura przedmiotu, praktycy budżetowi, a także Ministerstwo Finansów proponują zestawy wielu różnych wskaźników, które są wykorzystywane do oceny sytuacji finansowej gmin. Można je podzielić na wskaźniki dochodowe, wydatkowe, relacji dochodów i wydatków, a także wskaźniki zadłużenia i płynności finansowej ${ }^{13}$ lub na wskaźniki budżetowe, wskaźniki na

10 A. Stanisz, op. cit., s. 129.

11 Ibidem, s. 151.

${ }^{12}$ R. Arendarski, Możliwości wykorzystania analiz finansowych $w$ jednostkach samorzqdu terytorialnego, „Samorząd Terytorialny” 2010, nr 7-8, http://www.lex.pl/akt/-/akt/mozliwosci-wykorzystania-analiz-finansowych-w-jednostkach-samorzadu-terytorialnego [dostęp: 11.05.2016].

${ }_{13}$ A. Czudec, R. Kata, Metodyczne aspekty oceny gospodarki finansowej jednostek samorzadu terytorialnego, „Finanse Komunalne” 2012, nr 10, s. 9. 
mieszkańca lub wskaźniki zobowiązań według tytułów dłużnych. Drugi z wymienionych podziałów zaproponowany został przez Ministerstwo Finansów ${ }^{14}$. W dalszych analizach zostaną wykorzystane wskaźniki budżetowe. Przedstawiono je w tabeli 1 i wskazano na charakter zmiennej w kontekście kondycji finansowej JST i zdolności wykonywania zadań bieżących i inwestycyjnych. Stymulanty to mierniki, których wzrost jest korzystny dla gminy, destymulanty - przeciwnie ${ }^{15}$.

\section{Tabela 1}

Wskaźniki budżetowe służące do oceny sytuacji finansowej JST

\begin{tabular}{|c|c|c|}
\hline Wskaźniki budżetowe & Formula & $\begin{array}{l}\text { Charakter } \\
\text { zmiennej }\end{array}$ \\
\hline $\begin{array}{l}\text { Udział dochodów bieżących } \\
\text { w dochodach ogółem }\left(W_{\mathrm{B} 1}\right)\end{array}$ & $\begin{array}{l}W_{\mathrm{B} 1}=\frac{D b}{D o}, \text { gdzie } D b-\text { dochody bieżące, } \\
D o-\text { dochody ogółem }\end{array}$ & stymulanta \\
\hline $\begin{array}{l}\text { Udział dochodów własnych } \\
\text { w dochodach ogółem }\left(W_{\mathrm{B} 2}\right)\end{array}$ & $W_{\mathrm{B} 2}=\frac{D w}{D o}$, gdzie $D w-$ dochody własne & stymulanta \\
\hline $\begin{array}{l}\text { Udział nadwyżki operacyjnej } \\
\text { w dochodach ogółem }\left(W_{\mathrm{B} 3}\right)\end{array}$ & $W_{\mathrm{B} 3}=\frac{N o}{D o}$, gdzie $N o-$ nadwyżka operacyjna & stymulanta \\
\hline $\begin{array}{l}\text { Udział wydatków majątkowych } \\
\text { w wydatkach ogółem }\left(W_{\mathrm{B} 4}\right)\end{array}$ & $\begin{array}{l}W_{\mathbf{B} 4}=\frac{W m}{W o}, \text { gdzie } W m-\text { wydatki majątkowe, } \\
W o-\text { wydatki ogółem }\end{array}$ & stymulanta \\
\hline $\begin{array}{l}\text { Obciążenie wydatków bieżących } \\
\text { wydatkami na wynagrodzenia } \\
\left.\text { i pochodne od wynagrodzeń ( } W_{\mathrm{B} 5}\right)\end{array}$ & $\begin{array}{l}W_{\mathbf{B} 5}=\frac{W w}{W b}, \text { gdzie } W w-\text { wydatki na } \\
\text { wynagrodzenia i pochodne od wynagrodzeń, } \\
W b-\text { wydatki bieżące }\end{array}$ & destymulanta \\
\hline $\begin{array}{l}\text { Udział nadwyżki operacyjnej } \\
\text { i dochodów ze sprzedaży majątku } \\
\text { w dochodach ogółem }\left(W_{\mathrm{B} 6}\right)\end{array}$ & $\begin{array}{l}W_{\mathbf{B} 6}=\frac{N o+S m}{D o}, \text { gdzie } S m-\text { dochody ze sprzedaży } \\
\text { majątku }\end{array}$ & stymulanta \\
\hline Wskaźnik samofinansowania $\left(W_{\mathrm{B} 7}\right)$ & $\begin{array}{l}W_{\mathbf{B} 7}=\frac{N o+D m}{W m}, \text { gdzie } D m-\text { dochody majątkowe, } \\
W m \text { - wydatki majątkowe }\end{array}$ & stymulanta \\
\hline
\end{tabular}

Źródło: opracowanie własne na podstawie Wskaźniki do oceny sytuacji finansowej jednostek samorzqdu terytorialnego w latach 2012-2015, 2015, Ministerstwo Finansów, Warszawa, http://www.mf.gov. $\mathrm{pl} /$ ministerstwo-finansow/dzialalnosc/finanse-publiczne/budzety-jednostek-samorzadu-terytorialnego/ kwoty-i-wskazniki [dostęp: 2.11.2016].

${ }_{14}$ Ministerstwo Finansów: http://www.finanse.mf.gov.pl/c/document_library/get_file?uuid $=415 \mathrm{~b} 71 \mathrm{a} 8-53 \mathrm{c} 1-4 \mathrm{e} 3 \mathrm{~b}-\mathrm{ac} 1 \mathrm{~b}-\mathrm{e} 5 \mathrm{a} 59 \mathrm{f} 644038 \&$ groupId=766655 [dostęp: 4.11.2016].

${ }^{15}$ Charakter wskaźników budżetowych określono m.in. na podstawie opracowania A. Bieniasz, Z. Gołaś, A. Łuczak, Wielowymiarowa analiza kondycji finansowej gmin $w$ Polsce $w$ latach 2007-2011, „Wieś i Rolnictwo” 2014, nr 2(163), s. 104. W odniesieniu do wskaźnika $W_{\mathrm{B} 1}$ autorzy stwierdzaja, że „im wyższy poziom tego wskaźnika, tym większe możliwości realizowania zadań przez gminy”. Z punktu widzenia realizacji zadań uznano wskaźnik ten za stymulantę. Inaczej interpretuja go A. Czudec i R. Kata, op. cit., s. 9, wskazując, że jest on nominanta, a więc wartościa, która powinna mieścić się w konkretnym przedziale (podobnie $W_{\mathrm{B} 5}$ lub $W_{\mathrm{B} 7}$ ). Autorzy nie podają jednak jego górnych i dolnych wartości, ale wskazują na konieczność ustalenia jego wzorców, np. na podstawie średnich wskaźników dla gmin w Polsce, opinii ekspertów lub instytucji przetwarzających dane finansowe sektora samorządowego. Zagadnienie to wykracza poza ramy niniejszego opracowania, przyjęto więc interpretację A. Bieniasz et al. za wyjściową w interpretacji uzyskanych wyników. 
W pierwszym etapie badań dokonano analizy wskaźnikowej budżetów wszystkich gmin województwa warmińsko-mazurskiego w latach 20102014. Utworzony zbiór danych dał obszerny obraz sytuacji finansowej gmin $\mathrm{w}$ badanym okresie. Biorąc jednak pod uwagę to, że interpretacja większości wskaźników w poszczególnych latach nie jest jednoznaczna, np. z uwagi na zaciagnięte kredyty lub inwestycje, które sa rozliczane i realizowane w okresie kilkuletnim - uzasadnionym krokiem było uśrednienie wskaźników dla badanego okresu pięciu lat i poddanie średniej ich wartości dalszym analizom.

Tabela 2

Średnie wartości statystyczne wskaźników budżetowych gmin województwa warmińsko-mazurskiego w latach 2010-2014

\begin{tabular}{|l|c|c|c|c|c|c|c|}
\hline \multirow{2}{*}{$\begin{array}{c}\text { Miara } \\
\text { statystyczna }\end{array}$} & \multicolumn{5}{c|}{ Wskaźnik } \\
\cline { 2 - 8 } & $W_{\text {B1 }}$ & $W_{\text {B2 }}$ & $W_{\text {B3 }}$ & $W_{\text {B4 }}$ & $W_{\text {B5 }}$ & $W_{\text {B6 }}$ & $W_{\text {B } 7}$ \\
\hline $\begin{array}{l}\text { Wartość } \\
\text { maksymalna }\end{array}$ & 0,690 & 0,977 & 0,330 & 0,543 & 0,135 & 5,025 & 0,241 \\
\hline $\begin{array}{l}\text { Wartość } \\
\text { minimalna }\end{array}$ & 0,158 & 0,749 & 0,088 & 0,337 & $-0,022$ & 0,293 & $-0,067$ \\
\hline Rozstęp & 0,532 & 0,228 & 0,243 & 0,206 & 0,157 & 4,732 & 0,309 \\
\hline $\begin{array}{l}\text { Średnia } \\
\text { arytmetyczna }\end{array}$ & 0,385 & 0,903 & 0,176 & 0,431 & 0,051 & 1,121 & 0,046 \\
\hline $\begin{array}{l}\text { Odchylenie } \\
\text { standardowe }\end{array}$ & 0,110 & 0,044 & 0,049 & 0,039 & 0,034 & 0,635 & 0,060 \\
\hline $\begin{array}{l}\text { Współczynnik } \\
\text { zmienności (\%) }\end{array}$ & 28,69 & 4,820 & 27,670 & 9,120 & 67,86 & 56,67 & 132,240 \\
\hline $\begin{array}{l}\text { Współczynnik } \\
\text { skośności }\end{array}$ & 0,422 & $-0,749$ & 0,707 & 0,082 & 0,303 & 3,370 & 0,427 \\
\hline
\end{tabular}

Źródło: opracowanie własne na podstawie danych BDL GUS ${ }^{16}$ i danych Ministerstwa Finansów ${ }^{17}$.

Z uwagi na obszerność zestawienia wskaźników 116 gmin województwa, $\mathrm{w}$ tabeli 2 zaprezentowano jedynie zbiorcze dane dotyczące ich średnich wartości: maksymalnych, minimalnych, rozstępu - różnicy między maksymalną

16 Bank Danych Lokalnych GUS, https://bdl.stat.gov.pl/BDL/start [dostęp: 11.11.2016].

${ }_{17}$ MinisterstwoFinansów, http://www.finanse.mf.gov.pl/c/document_library/get_file?uuid=415b 71a8-53c1-4e3b-ac1b-e5a59f644038\&groupId=766655 [dostęp: 4.11.2016]. 
i minimalną wartościa, średniej arytmetycznej oraz odchylenia standardowego, współczynnika zmienności i skośności.

W badaniu przyjęto założenie o normalności rozkładu badanych $\operatorname{cech}^{18}$, jednak należy zauważyć, że współczynnik skośności, który dla rozkładu symetrycznego przyjmuje wartości bliskie 0 (zazwyczaj z przedziału od -1 do $1^{19}$ ). W przypadku wskaźnika $W_{\mathrm{B} 6}$ osiagną poziom aż 3,37, co świadczy o silnej, prawostronnej asymetrii. Oznacza to, że większość gmin uzyskuje niższe jego wartości niż średnia jego wartość. Jak się wskazuje ${ }^{20}$, asymetria prawostronna dla dochodów jest typowa. Własność ta może nieznacznie obciążać wyniki grupowania.

Najważniejszymi właściwościami, jakimi muszą charakteryzować się zmienne brane pod uwagę przy klasyfikacjach, to: mierzalność, sumowalność, niezależność oraz zmiennośćc ${ }^{21}$. Mierzalność cech sprowadza się do wyrażania liczbowego cech. Sumowalność (porównywalność) cech wymaga natomiast przeprowadzenia tzw. standaryzacji, do której zastosowana została formuła:

$$
z=\frac{x-\mu}{\sigma}
$$

gdzie: $z$-zmienna po standaryzacji, $x$-zmienna niestandaryzowana, $\mu$ - średnia z populacji, $\sigma$-odchylenie standardowe populacji.

Określenie wzajemnej niezależności cech dokonywane jest przez pomiar korelacji pomiędzy cechami. Macierz współczynników korelacji Pearsona dla wskaźników budżetowych przedstawia tabela 3. Między wskaźnikami $W_{\mathrm{B} 3}$ i $W_{\mathrm{B} 2}$ oraz $W_{\mathrm{B} 3}$ i $W_{\mathrm{B} 5}$ występuje silna korelacja, co potwierdza wartość współczynnika korelacji powyżej $0,5^{22}$ oraz przeprowadzone testy istotności korelacji przy założonym poziomie istotności $\alpha<0,05$. Wartość testu $t$-Studenta dla pierwszej pary wskaźników wyniosła $\left|t_{1}\right|=9,17$, dla drugiej $\left|t_{2}\right|=6,49$. Wartości te są większe niż wartość krytyczna testu dla 114 stopni swobody odczytana z tablic rozkładu $t$-Studenta $(\mathrm{t}=1,98)$. W związku z tym należało przyjaćc hipotezę o istnieniu silnej korelacji pomiędzy wymienionymi wskaźnikami. W konsekwencji postanowiono wyeliminować wskaźnik $W_{\mathrm{B} 3}$ z dalszych analiz.

Warunek zmienności cech został spełniony dla wskaźników $W_{\mathrm{B} 1}, W_{\mathrm{B} 3}, W_{\mathrm{B} 5}$, $W_{\mathrm{B} 6}$ oraz $W_{\mathrm{B} 7}$, na co wskazał współczynnik zmienności przedstawiony w tabeli 2. Wartość współczynnika powyżej 10\% świadczy o dużym zróżnicowaniu (statystycznej zmienności) cechy ${ }^{23}$. Poza wskaźnikiem $W_{\mathrm{B} 2}$ oraz $W_{\mathrm{B} 4}$ pozostałe wskaźniki charakteryzują się dużą zmiennością. Cechy, które charakteryzuja się małym zróżnicowaniem, nic nie wnoszą do przeprowadzanej klasyfikacji.

18 To sugestia J. Paryska, Modele klasyfikacji w geografii, WN UAM, Poznań 1982, s. 47-48, który stwierdził, że dla zjawisk geograficzno-ekonomicznych oraz społecznych zakłada się z góry rozkład normalny lub dwumianowy: „w praktyce zagadnienie rozkładu statystycznego wygląda jednak w taki sposób, iż zakłada się o zmiennych, że charakteryzuje je określony rozkład statystyczny, stosownie do którego stosuje się odpowiednie metody analizy ilościowej. Założenie to dotyczy przeważnie rozkładu normalnego".

19 A. Stanisz, op. cit., s. 125.

20 S. M. Kot, J. Jakubiowski, A. Sokołowski, Statystyka, Difin, Warszawa 2011, s. 183.

21 J. Parysek, op. cit., s. 31.

${ }_{22}$ T. Panek, J. Zwierzchowski, Statystyczne metody wielowymiarowej analizy porównawczej. Teoria $i$ zastosowania, Oficyna Wydawnicza SGH, Warszawa 2013, s. 23.

${ }^{23}$ T. Panek, J. Zwierzchowski, op. cit., s. 22. 
Mogą one natomiast obciążyć procedurę klasyfikacyjną i utrudniać interpretację wyników. Klasyfikacja powinna uwzględniać więc jedynie znaczące różnice i podobieństwa w zbiorze badanych obiektów. Cechy o małym zróżnicowaniu należy pominaćc, nawet jeśli są merytorycznie istotne z punktu widzenia prowadzonych badań.

W związku z powyższym ostatecznie do dalszych analiz został zastosowany zbiór czterech wskaźników: $W_{\mathrm{B} 1}, W_{\mathrm{B} 5}, W_{\mathrm{B} 6}, W_{\mathrm{B} 7}$. Spełniają one wymogi stawiane zmiennym branym pod uwagę w klasyfikacjach.

\section{Tabela 3}

Macierz współczynników korelacji Pearsona wskaźników budżetowych

\begin{tabular}{|c|c|c|c|c|c|c|c|}
\hline & $W_{\mathrm{B} 1}$ & $W_{\mathrm{B} 2}$ & $W_{\mathrm{B} 3}$ & $W_{\mathrm{B} 4}$ & $W_{\mathrm{B} 5}$ & $W_{\mathrm{B} 6}$ & $W_{\mathrm{B} 7}$ \\
\hline$W_{\mathrm{B} 1}$ & 1,000 & & & & & & \\
\hline$W_{\mathrm{B} 2}$ & $-0,328$ & 1,000 & & & & & \\
\hline$W_{\mathrm{B} 3}$ & 0,300 & $-0,642$ & 1,000 & & & & \\
\hline$W_{\mathrm{B} 4}$ & $-0,024$ & 0,112 & $-0,086$ & 1,000 & & & \\
\hline$W_{\mathrm{B} 5}$ & 0,142 & $-0,130$ & 0,519 & $-0,042$ & 1,000 & & \\
\hline$W_{\mathrm{B} 6}$ & $-0,213$ & 0,035 & $-0,208$ & 0,161 & 0,134 & 1,000 & \\
\hline$W_{\mathrm{B} 7}$ & 0,239 & $-0,290$ & 0,361 & $-0,056$ & 0,488 & $-0,044$ & 1,000 \\
\hline
\end{tabular}

Źródło: opracowanie własne na podstawie wyników badań.

\section{PRÓBA KLASYFIKACJI GMIN ZE WZGLĘDU NA ICH SYTUACJĘ FINANSOWA}

Do przeprowadzenia grupowania metodą $k$-średnich przyjęto podział gmin na pięć grup, na co wskazał uzyskany na skutek zastosowania metody aglomeracji dendagram (wykres 1). W badanym okresie w zbiorowości gmin województwa warmińsko-mazurskiego wystapiło od 2 do 5 podstawowych grup gmin. Dalsze uszczegóławianie gmin mijałoby się z celem klasyfikacji, gdyż gminy zgrupowane w kolejnych skupieniach są mniej jednorodne, a odległości wiązań między nimi coraz mniejsze. W związku z tym przyjęto podział gmin na pięć grup (miejsce „odcięcia” zaznaczono linią przerywaną na wykresie 1), co uzasadniaja powyższe względy statystyczne oraz inne badania prowadzone w zakresie m.in. finansów lokalnych, które w celach opisowych dzielą badana zbiorowość także na pięć grup ${ }^{24}$.

${ }^{24}$ Monitoring rozwoju obszarów wiejskich. Etap II. Przestrzenne zróżnicowanie poziomu rozwoju społeczno-gospodarczego obszarów wiejskich, IRWiR PAN, Warszawa 2016, s. 111-121. 


\section{Wykres 1}

Dendagram grupowania gmin na podstawie ich sytuacji finansowej w latach 2010-2014

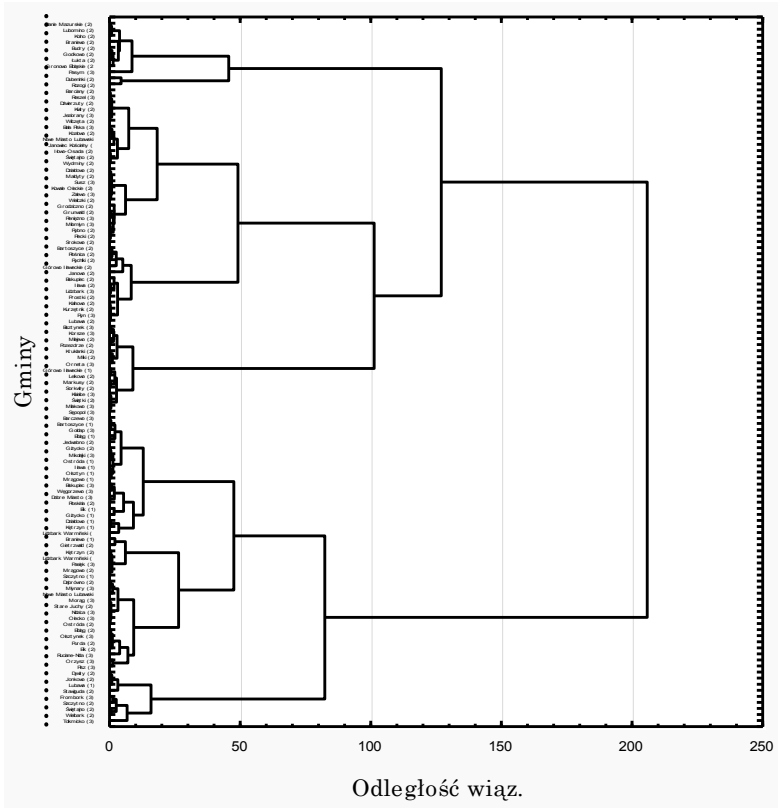

Źródło: opracowanie własne na podstawie wyników badań.

W następnym kroku za pomoca programu STATISTICA v. 12 zostały posortowane odległości między skupieniami, a następnie na początkowe centra skupień wybrane zostały obiekty przy stałych interwałach. Klasyfikacja została ustalona już w trzeciej iteracji. Liczebność poszczególnych skupień oraz średnie wskaźniki budżetowe w grupach zaprezentowano w tabeli 4 oraz na wykresie 2 .

\section{Tabela 4}

Liczebność grup i średnie wartości standaryzowanych wskaźników budżetowych gmin w grupach

\begin{tabular}{|l|c|c|c|c|c|}
\cline { 3 - 6 } \multicolumn{1}{c|}{} & \multirow{2}{*}{$\begin{array}{c}\text { Liczebność } \\
\text { grupy }\end{array}$} & \multicolumn{4}{|c|}{ Średnia arytmetyczna } \\
\cline { 3 - 6 } \multicolumn{1}{c|}{} & $\boldsymbol{W}_{\text {B1 }}$ & $\boldsymbol{W}_{\text {B5 }}$ & $\boldsymbol{W}_{\text {B6 }}$ & $\boldsymbol{W}_{\text {B7 }}$ \\
\hline Grupa 1 & 39 & 1,015 & 0,101 & $-0,267$ & 0,552 \\
\hline Grupa 2 & 10 & $-0,663$ & $-0,062$ & 2,544 & $-0,538$ \\
\hline Grupa 3 & 22 & $-0,947$ & $-0,123$ & $-0,220$ & $-0,146$ \\
\hline Grupa 4 & 18 & $-0,503$ & 1,402 & 0,025 & 1,001 \\
\hline Grupa 5 & 27 & $-0,115$ & $-0,950$ & $-0,393$ & $-1,149$ \\
\hline
\end{tabular}

Źródło: opracowanie własne na podstawie wyników badań. 


\section{Wykres 2}

Wartości średnie poszczególnych standaryzowanych wskaźników budżetowych w grupach gmin

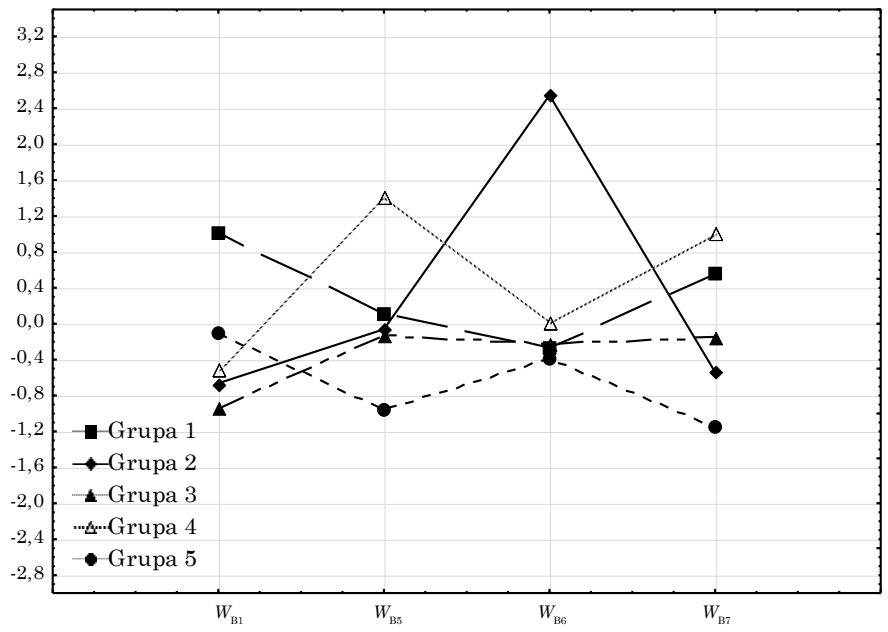

Źródło: opracowanie własne na podstawie wyników badań.

Interpretacja uzyskanych wyników pozwala wskazać, że pierwsza grupę stanowia gminy o stabilnej sytuacji finansowej. Świadczy o tym wysoki udział dochodów bieżących w dochodach ogółem $\left(W_{\mathrm{B} 1}\right)$. Dochody bieżące to wszystkie dochody budżetowe poza majątkowymi, które mają charakter incydentalny i trudny do przewidzenia. Dochody bieżące są natomiast gromadzone w sposób systematyczny i stały. Im wyższa wartość tego wskaźnika, tym większe możliwości realizowania zadań przez gminę $e^{25}$. Ponadto gminy te charakteryzuje relatywnie wysoki udział wydatków i pochodnych od wynagrodzeń w wydatkach bieżących $\left(W_{\mathrm{B} 5}\right)$, co jest niekorzystną sytuacją. Wskaźnik ten informuje o tzw. sztywności budżetu, ponieważ wydatki na wynagrodzenia bardzo trudno ograniczyć. Negatywnie można ocenić również niski udział nadwyżki operacyjnej i dochodów ze sprzedaży majątku w dochodach ogółem $\left(W_{\mathrm{B} 6}\right)$. Gminy te nie mogą swobodnie zaciagać zobowiązań o charakterze rozwojowym i prowadzić nowych inwestycji. Niekorzystna sytuacja zachodzi także w przypadku relatywnie wysokiego wskaźnika samofinansowania $\left(W_{\mathrm{B} 7}\right)$, która wynika z mniejszych wydatków majątkowych gmin. Zazwyczaj im niższa jest jego wartość, tym większe jest ryzyko utraty płynności finansowej w związku z nadmiernymi kosztami obsługi zadłużenia. Z drugiej strony możliwa jest sytuacja, w której gminy, chociaż nie mają zadłużenia, osiagają niski poziom wskaźnika samofinansowania. Taka sytuacja może świadczyć o wysokim poziomie realizowanych $\mathrm{w}$ badanym okresie inwestycji, co nastapiło $\mathrm{w}$ badanym okresie $\mathrm{w}$ wielu gminach grupy 1 .

Grupa druga składa się z gmin o niskim udziale dochodów bieżących w dochodach ogółem $\left(W_{\mathrm{B} 1}\right)$, co może świadczyć o relatywnie niestabilnej sytuacji

25 A. Bieniasz, Z. Gołaś, A. Łuczak, op. cit., s. 105-106. 
finansowej. Względnie niski jest także udział wydatków na wynagrodzenia i pochodne od wynagrodzenia w wydatkach bieżaccych $\left(W_{\mathrm{B} 5}\right)$, co z kolei jest korzystne i świadczy o istniejącej elastyczności budżetu. Uwagę zwraca szczególnie wysoki udział nadwyżki operacyjnej i dochodów ze sprzedaży majątku w dochodach ogółem $\left(W_{\mathrm{B} 6}\right)$ gmin na tle pozostałych grup. Jest to zjawisko pozytywne, proinwestycyjne i prorozwojowe. Grupa druga charakteryzuje się jednak niskim wskaźnikiem samofinansowania $\left(W_{\mathrm{B} 7}\right)$, co informuje o relatywnie małych możliwościach finansowania inwestycji środkami własnymi lub o relatywnie wysokich wydatkach majątkowych.

Grupa trzecia charakteryzuje się najmniej stabilną sytuacją finansowa, na co wskazuje niski udział dochodów bieżących w dochodach ogółem $\left(W_{\mathrm{B} 1}\right)$. Gminy te także wykazuja istnienie elastyczności w kształtowaniu wydatków z uwagi na relatywnie niski udział wydatków na wynagrodzenia i pochodne od wynagrodzeń w wydatkach ogółem $\left(W_{\mathrm{B} 5}\right)$. Ponadto, podobnie jak w grupie pierwszej, gminy grupy trzeciej charakteryzuje niski udział nadwyżki operacyjnej i dochodów ze sprzedaży majątku w dochodach ogółem $\left(W_{\mathrm{B} 6}\right)$. Gminy te nie moga więc swobodnie zaciagać zobowiązań o charakterze rozwojowym i prowadzić inwestycji. Średnia wartość wskaźnika samofinansowania $\left(W_{\mathrm{B} 7}\right)$ tej grupy świadczy o tym, że gminy te w relatywnie niewielkim stopniu finansują inwestycje z własnych środków.

Grupa czwarta charakteryzuje się względnie niskim udziałem dochodów bieżących w dochodach ogółem $\left(W_{\mathrm{B} 1}\right)$, co jest niekorzystną sytuacją. Gminy te osiagaja najwyższy spośród wszystkich grup średni wskaźnik udziału wynagrodzeń i pochodnych od wynagrodzeń w wydatkach ogółem $\left(W_{\mathrm{B} 5}\right)$. Oznacza to najmniejszą elastyczność ich budżetów. Względnie wysoki jest jednak wskaźnik udziału nadwyżki operacyjnej i dochodów ze sprzedaży majątku w dochodach ogółem $\left(W_{\mathrm{B} 6}\right)$. Wskazuje to na możliwość prowadzenia inwestycji i zaciągania zobowiazań. Potwierdza to wysoki średni wskaźnik samofinansowania $\left(W_{\mathrm{B} 7}\right)$, który oznacza relatywnie małe ryzyko utraty płynności finansowej, choć może świadczyć także o niskich inwestycjach ${ }^{26}$.

Grupa piąta, poza średnim udziałem dochodów bieżących w dochodach ogółem $\left(W_{\mathrm{B} 1}\right)$, charakteryzuje się najniższymi wartościami pozostałych wskaźników na tle innych grup. W przypadku udziału wydatków na wynagrodzenia i pochodne od wynagrodzeń w wydatkach bieżących $\left(W_{\mathrm{B} 5}\right)$ jest to zjawisko pozytywne, mówiące o relatywnie dużej elastyczności budżetów. Dwa pozostałe wskaźniki świadczą o relatywnie małych możliwościach prowadzenia inwestycji i zaciagania zobowiązań oraz o istniejącym ryzyku utraty płynności finansowej.

W interpretacji wyników przeprowadzonej klasyfikacji ważnym etapem jest profilowanie uzyskanych grup. Profilowanie pozwala na wskazanie podobieństw lub różnic pomiędzy gminami zaklasyfikowanymi do określonych grup pod względem cech, które nie brały udziału w przeprowadzonej klasyfikacji ${ }^{27}$. W tym celu zastosowano dwa kryteria - status prawny gminy (miejska, miejsko-wiejska lub wiejska) oraz położenie administracyjne gmin.

\footnotetext{
26 Ibidem, s. 105.

${ }^{27}$ M. Walesiak, op. cit., s. 67.
} 
W tabeli 5 przedstawiono liczebności poszczególnych grup gmin ze względu na ich status prawny. Gminy miejskie zakwalifikowały się w większości do grupy pierwszej, trzy z nich do grupy piątej. Gminy miejsko-wiejskie znalazły się w każdej grupie, jednak największy udział mają w grupie trzeciej (82\%). Większość gmin wiejskich (24 z 33 gmin), znalazła się w grupie pierwszej i piątej. Dwa miasta na prawach powiatu: Elblag i Olsztyn zakwalifikowały się do grupy pierwszej.

Tabela 5

Liczebność grup według statusu prawnego gmin

\begin{tabular}{|l|c|c|c|c|c|c|}
\hline \multicolumn{1}{|c|}{ Gminy } & Grupa 1 & Grupa 2 & Grupa 3 & Grupa 4 & Grupa 5 & Suma \\
\hline miejskie & $\begin{array}{c}11 \\
(28,21 \%)\end{array}$ & - & - & - & $\begin{array}{c}3 \\
(11,11 \%)\end{array}$ & 14 \\
\hline miejsko-wiejskie & $\begin{array}{c}14 \\
(35,89 \%)\end{array}$ & $\begin{array}{c}9 \\
(90 \%)\end{array}$ & $\begin{array}{c}18 \\
(81,82 \%)\end{array}$ & $\begin{array}{c}14 \\
(77,78 \%)\end{array}$ & $\begin{array}{c}12 \\
(44,44 \%)\end{array}$ & 67 \\
\hline wiejskie & $\begin{array}{c}12 \\
(30,77 \%)\end{array}$ & $\begin{array}{c}1 \\
(10 \%)\end{array}$ & $\begin{array}{c}4 \\
(18,18 \%)\end{array}$ & $\begin{array}{c}4 \\
(22,22 \%)\end{array}$ & $\begin{array}{c}12 \\
(44,44 \%)\end{array}$ & 33 \\
\hline $\begin{array}{l}2 \\
\text { miasta na pra- }\end{array}$ & $\begin{array}{c}2 \\
\text { wach powiatu }\end{array}$ & - & - & - & - & 2 \\
\hline Suma & $\begin{array}{c}39 \\
(100 \%)\end{array}$ & $\begin{array}{c}10 \\
(100 \%)\end{array}$ & $\begin{array}{c}22 \\
(100 \%)\end{array}$ & $\begin{array}{c}18 \\
(100 \%)\end{array}$ & $\begin{array}{c}27 \\
(100 \%)\end{array}$ & 116 \\
\hline
\end{tabular}

Źródło: opracowanie własne na podstawie wyników badań.

Na wykresie 3 przedstawiono mapę województwa w podziale na gminy należące do poszczególnych grup. Można zauważyć, że podobna sytuacja finansowa dotyczy gmin sasiadujących ze stolica województwa - Olsztynem oraz z pozostałymi dużymi miastami regionu: Elblagiem, Ełkiem, Ostróda, Lidzbarkiem Warmińskim i Mragowem. Gminy te należą głównie do grupy pierwszej i piątej.

Dzięki przeprowadzonej klasyfikacji można utworzyć ranking uzyskanych grup gmin ze względu na cechy opisujące ich budżety (stabilność budżetu, sztywność budżetu, możliwości inwestycyjne oraz możliwości samofinansowania). Próbę utworzenia rankingu przedstawiono w tabeli 6. Pozycja rankingowa dla poszczególnych cech wynikała z wartości średniego wskaźnika budżetowego w danej grupie i została ustalona w przedziale od 1 do 5 ( 1 - pierwsza pozycja z najwyższym wynikiem, 5 - najsłabsza, z najniższym wynikiem). $\mathrm{Z}$ racji tego, że wskaźnik $W_{\mathrm{B} 5}$ (tzw. sztywności budżetu) ma charakter destymulanty, pozycję rankingową określono przeciwnie: 1 - pozycja o najniższym wynikiem, 5 - o najwyższym, a więc najgorszym wyniku. Pozycje rankingowe za poszczególne wskaźniki dla wyodrębnionych grup gmin zostały zsumowane. Najniższa ich wartość świadczy o relatywnie najlepszej pozycji w rankingu. 


\section{Wykres 3}

Grupy gmin województwa warmińsko-mazurskiego ze względu na ich sytuację finansowa

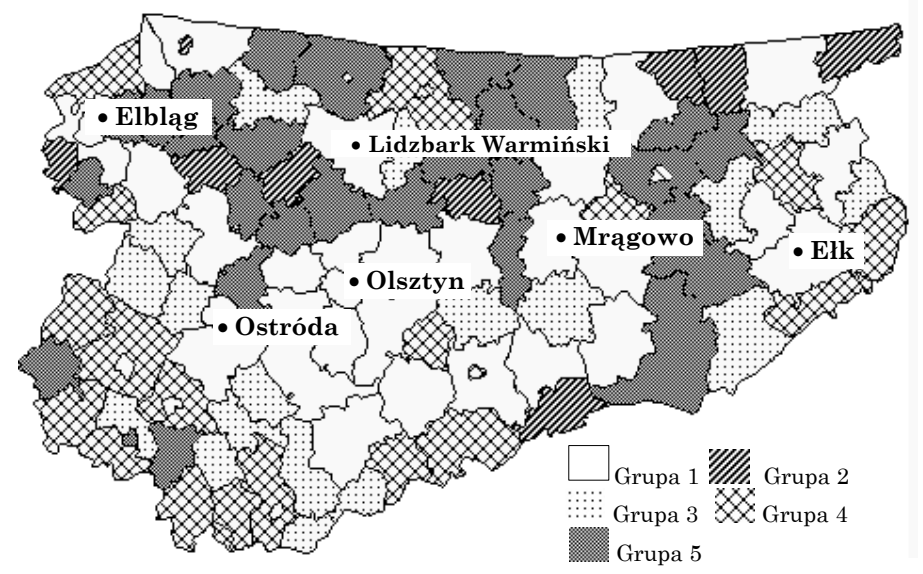

Źródło: opracowanie własne na podstawie wyników badań.

Najlepszą i podobna sytuacja finansowa na tle pozostałych gmin województwa charakteryzowały się gminy należące do grup pierwszej i czwartej. Łącznie sytuacja ta dotyczyła 57 gmin województwa. Znajdują się wśród nich przede wszystkim gminy miejsko-wiejskie (28), gminy miejskie (11), miasta na prawach powiatu (2) i gminy wiejskie (16). Z wykresu 3 wynika, że gminami tymi sa przede wszystkim te, które sa położone w pobliżu największych miast regionu. Na kolejnym miejscu w rankingu znalazła się grupa druga złożona z 10 gmin - 9 gmin miejsko-wiejskich i 1 wiejskiej. Najgorzej sytuacja finansowa kształtowała się w gminach grup trzeciej i piątej złożonych łącznie z 49 gmin.

Tabela 6

Ranking grup gmin według cech budżetu

\begin{tabular}{|c|c|c|c|c|c|c|}
\hline Grupa & $\begin{array}{c}\text { Stabilność } \\
\text { budżetu }\end{array}$ & $\begin{array}{c}\text { Sztyw- } \\
\text { ność } \\
\text { budżetu }\end{array}$ & $\begin{array}{c}\text { Możliwo- } \\
\text { ści inwe- } \\
\text { stycyjne }\end{array}$ & $\begin{array}{c}\text { Możliwo- } \\
\text { ści samofi- } \\
\text { nansowa- } \\
\text { nia }\end{array}$ & Suma & $\begin{array}{c}\text { Pozycja } \\
\text { rankingo- } \\
\text { wa }\end{array}$ \\
\hline Grupa 1 & 1 & 4 & 4 & 2 & 11 & $\mathbf{1 - 2}$ \\
\hline Grupa 2 & 4 & 3 & 1 & 4 & 12 & $\mathbf{3}$ \\
\hline Grupa 3 & 5 & 2 & 3 & 3 & 13 & $\mathbf{4 - 5}$ \\
\hline Grupa 4 & 3 & 5 & 2 & 1 & 11 & $\mathbf{1 - 2}$ \\
\hline Grupa 5 & 2 & 1 & 5 & 5 & 13 & $\mathbf{4 - 5}$ \\
\hline
\end{tabular}

Źródło: opracowanie własne na podstawie wyników badań. 


\section{PODSUMOWANIE I WNIOSKI}

Na podstawie średniej wartości wskaźników budżetowych gmin województwa warmińsko-mazurskiego w latach 2010-2014 przeprowadzono klasyfikację gmin z punktu widzenia oceny ich sytuacji finansowej. W wyniku grupowania metodą $k$-średnich dokonano podziału gmin na pięć grup.

Jednoznaczna ocena sytuacji finansowej gmin zaklasyfikowanych do danej grupy nie jest w pełni możliwa przy wykorzystaniu zaproponowanych czterech wskaźników budżetowych. Brak jednoznaczności w ocenie potwierdza tezę o złożoności badanego problemu i istnieniu wielu czynników, które w różny sposób oddziałują na budżety gmin. Wskazuje na to przeprowadzony ranking grup gmin, którego efektem było wyłonienie grup o relatywnie lepszej sytuacji finansowej (grupa pierwsza i czwarta) oraz pozostałych grup, o gorszej sytuacji finansowej (grupa druga, trzecia i piąta). Różnice w ocenie rankingowej między grupami nie były jednak znaczące. Każda z wyodrębnionych grup gmin, poza grupą trzecią ze względu na któreś kryterium oceny budżetu zajęła najlepszą pozycję. Każda też grup zajęła najgorszą lub dwukrotnie przedostatnią pozycję.

Ocena sytuacji finansowej danej grupy zależy od wskaźnika przyjętego na potrzeby tej oceny. Można by również rozważyć nadanie wskaźnikom wykorzystanym w badaniu wag, które odzwierciedlałyby znaczenie mierzonych przez te wskaźniki cech budżetu. Wagi te miałyby jednak charakter subiektywny i wskazywałyby na konkretny aspekt gospodarki budżetowej (np. na samodzielność finansową lub możliwość zaciagania zobowiązań). Innym rozwiązaniem zaistniałej trudności w ocenie sytuacji finansowej uzyskanych grup gmin mogłoby być zastosowanie dodatkowego kryterium oceny np. wskaźników dochodów lub wydatków w przeliczaniu na mieszkańca gmin lub wskaźników służących do oceny zadłużenia jednostki.

Narzędziem pomocnym w interpretacji efektów klasyfikacji było tzw. profilowanie otrzymanych grup. Przeprowadzono je, biorac pod uwage status prawny gmin oraz ich położenie geograficzne. $\mathrm{Z}$ analiz tych wynika, że jedynie połowa jednostek, głównie o statusie miejskim i miejsko-wiejskim charakteryzowała się w badanym okresie relatywnie dobrymi wynikami budżetowymi. Pozostałe gminy miały gorszą sytuację finansowa. Analiza przestrzenna poszczególnych grup gmin potwierdziła, że lepszą sytuację finansową wykazywały gminy położone w sąsiedztwie stolicy województwa i innych większych miast regionu.

Zaprezentowane w artykule badania mogą stanowić podstawę do dalszych poszukiwań odpowiedzi na pytanie o szczegółowe przyczyny istniejącego rozwarstwienia sytuacji finansowej gmin województwa warmińsko-mazurskiego. Analiza taka powinna być prowadzona przy uwzględnieniu dodatkowych kryteriów opisujących również sytuację pozabudżetowa gmin. One bowiem determinuja poziom i strukturę budżetu. 


\section{AN ATTEMPT TO CLASSIFY THE MUNICIPALITIES OF THE WARMIA-MAZURY REGION FROM THE POINT OF VIEW OF THEIR FINANCIAL CONDITION}

\section{Sum mary}

This article is an attempt to classify the municipalities (gminas) of Warmia and Mazury from the point of view of their financial condition. The research was carried out in years 20102014 , and covered all the municipalities of the region. To achieve the purpose a method of group $k$-means was used. Four budget indicators proposed by the Ministry of Finance were hallmarks of local budgets used in the research. As a result of the classification, five groups of municipalities were identified and characterised by their budgetary situation. Next a ranking of the groups of municipalities was made. The groups of municipalities were also profiled with regard to their legal status and geographical location. The studies have shown that in the analysed period, only 57 of the 116 municipalities of the Warmia-Mazury enjoyed a relatively good financial condition. Other municipalities received a low evaluation of the budget and have been classified into three other groups of municipalities. 
